\title{
Episodic recruitment in Antarctic krill Euphausia superba in the Palmer LTER study region
}

\author{
Langdon B. Quetin*, Robin M. Ross \\ Marine Science Institute, University of California at Santa Barbara, Santa Barbara, California 93106, USA
}

\begin{abstract}
As part of the Palmer Long-Term Ecological Research (LTER) program, the size structure of the population of Antarctic krill found between Anvers and Adelaide Islands west of the Antarctic Peninsula has been analyzed for patterns in recruitment success. The data were from a series of 11 cruises, 1 in spring (November 1991) and 10 in summer (January 1993 to January 2002). A maximum-likelihood fitting procedure was used to fit a mixture of normal distributions to the length-density distributions derived from net data. The recruitment index was calculated as the proportion of age-class 1 krill of the total. Antarctic krill in the Palmer LTER region showed a pattern of episodic recruitment, with 2 strong year classes in succession followed by 3 or 4 moderate or poor year classes. The 2 strong year classes represented 85 to $90 \%$ of the krill caught for 5 or 6 yr, and as the absolute abundance of the year class declined due to mortality, so did the abundance of Antarctic krill in the region. The recruitment index was positively correlated with the absolute value of a seasonal El Niño/Southern Oscillation (ENSO) index, with strongest recruitment during the neutral or moderate periods of ENSO. The mechanism underlying the strong link between the recruitment index and ENSO is most likely the effects of seasonal sea-ice dynamics on both reproduction and winter-over survival of the resulting larvae as previously documented.
\end{abstract}

KEY WORDS: Episodic recruitment · Antarctic krill · Polar zooplankton

Resale or republication not permitted without written consent of the publisher

\section{INTRODUCTION}

Antarctic krill Euphausia superba are a key species in the functioning of the pelagic ecosystem of the Southern Ocean. Antarctic krill has roles both as a dominant macro-zooplankton grazer in some regions (Miller \& Hampton 1989) and as an important prey item for many of the vertebrate predators (Laws 1985, Everson 2000). Variations in abundance and size distribution of populations of Antarctic krill therefore have implications outside those for the population dynamics of the species alone. Variations in krill abundance have been attributed to water mass shifts (Priddle et al. 1988), to horizontal seasonal/ontogenetic migrations (Siegel 1988), and to transport by large-scale ocean currents (Murphy et al. 1998). Alternatively, patterns in abundance may be due to variation in recruitment processes if a significant proportion of the population is retained in the study region, as suggested by Ichii et al.
(1998) and Lascara et al. (1999). Thus recruitment of Antarctic krill is fundamental to our understanding of the ecology of the Southern Ocean.

Previous studies have clearly demonstrated that recruitment success in Antarctic krill is highly variable (Siegel \& Loeb 1995, Siegel et al. 1998, 2002, Watkins 1999, Siegel 2000a), leading to significant interannual differences in the population structure and, potentially, abundance. Priddle et al. (1988) suggested that a failure in recruitment in 1 year could result in a 3 - to 4 -fold variation in the density of Euphausia superba and that recovery to initial densities might take several years of good recruitment. Based on the correlation of recruitment and seasonal sea-ice dynamics (Siegel \& Loeb 1995), and a warming trend in the Antarctic Peninsula (Smith \& Stammerjohn 2001), Loeb et al. (1997) speculated that a warming climate might alter the population dynamics of Antarctic krill and its availability to predators in the region. Variation in recruitment in 
long-lived marine species appears to be the rule and not the exception. In several time-series studies of fish, the population dynamics of the populations were largely driven by episodic recruitment. For rockfish populations off the coast of southern California (Mearns 1979) and anchovy in the Bay of Biscay (Allain et al. 2001), 8- and 12-yr time-series studies documented the variability. For the black bream in SE Australia, the age structure documented in a 4-yr study suggested that episodic recruitment had been the norm for at least $15 \mathrm{yr}$ (Morison et al. 1998). Although documentation of episodic recruitment in marine crustaceans is not common, Dayton (1989) showed that an Antarctic sponge had several years of near-zero recruitment that were followed by years of extremely high recruitment. E. superba is a long-lived crustacean, estimated to live from 5 to $8 \mathrm{yr}$ in the environment (Siegel 2000b, Nicol 2000), and capable of rematuration. E. superba may reproduce in its third summer (CuzinRoudy 1987a,b, Siegel \& Loeb 1994), but usually does not reproduce until its fourth summer west of the Antarctic Peninsula (Ross \& Quetin 2000). Depending on food conditions, an individual may reproduce each subsequent summer or delay reproduction (Ross \& Quetin 2000, Quetin \& Ross 2001). Long life, large size and multiple spawning seasons are life-history characteristics of a $K$-selected species that are shared by Antarctic krill (Siegel 1988) and that allow a sequence of failures followed by successes in recruitment to sustain the population.

The life cycle begins in September (early spring), when the ovary begins to develop, with spawning west of the Antarctic Peninsula in summer (mid-December through March). Antarctic krill rely on springtime primary production (ice-associated and open-water primary production) to fuel ovarian development, not stored reserves (Ross \& Quetin 1986, 2000, Nicol et al. 1995, Hagen et al. 1996, Quetin \& Ross 2001). Antarctic krill are multiple spawners, with reproducing females bringing several batches of eggs to maturity in 1 cycle, and are capable of repeating the ovarian maturation cycle if food conditions are adequate (Ross \& Quetin 1983, 1986, Cuzin-Roudy 1987a,b, 2000, CuzinRoudy \& Labat 1992, Quetin \& Ross 2001). In the Palmer Long-Term Ecological Research (LTER) study region west of the Antarctic Peninsula, interannual variability in intensity of reproduction has been over 10-fold (Quetin \& Ross 2001). Such variability leads to wide fluctuations in 'recruitment potential' or the number of potential recruits entering the ecosystem in the summer, as was observed early in the 1980s by Brinton et al. (1986, 1987). Larval development is long and complex, lasting throughout the first winter of life. Larval survival in the first year of life is the second factor in recruitment success or failure. Of the 2 periods when food availability appears to be critical for larval survival (Ross \& Quetin 1991), the first is when larvae metamorphose to the first feeding stage (Ross \& Quetin 1989). The second is the first winter, when food availability in the water column is low, and larvae may need to utilize food sources other than the microbial community in the water column (Ross \& Quetin 1991).

The concept that recruitment success in Antarctic krill is linked to sea ice has been in existence for over a decade (Smetacek et al. 1990). Several lines of evidence supported the linkage. First, in winter SCUBA divers observed larvae closely coupled to the underside of the sea ice and feeding on ice surfaces (Guzman 1983, Spiridonov et al. 1985, Kottmeier \& Sullivan 1987, O'Brien 1987, Marschall 1988). Second, larvae from ice-covered waters were in better physiological condition than those from open water (Ross \& Quetin 1991). Subsequent studies have confirmed that in winter larval krill usually inhabit the underside of the ice and the water column immediately below the ice (Melnikov \& Spiridonov 1996, Quetin et al. 1996, Frazer et al. 2002). Siegel \& Loeb (1995) used timeseries data $(14 \mathrm{yr})$ to test the correlations between an index of recruitment success for Antarctic krill and seaice dynamics. In the northern Antarctic Peninsula region, good recruitment was positively correlated with early spawning, the time of ice retreat, the duration of ice cover, and above-average spatial ice extent (Siegel \& Loeb 1995).

The time series for the Palmer LTER, sited west of the Antarctic Peninsula and about $450 \mathrm{~km}$ south of the long-term study site at the tip of the Antarctic Peninsula, was established in the 1991-1992 austral field season (Quetin \& Ross 1992, Smith et al. 1995). One goal of the sampling regime was to document variability in both reproduction and recruitment in the population of Antarctic krill found in the continental shelf and slope region extending from Anvers to Adelaide Islands. Evidence at the time suggested that there were 1 or 2 gyres within this region that would tend to retain the population and minimize advective emigration and immigration (Stein 1988, Stein \& Heywood 1994, Hofmann et al. 1996). Data were collected to test 2 hypotheses relevant to krill population dynamics (Quetin et al. 1996). The first hypothesis, about the effect of sea ice on reproduction, was tested with the time-series data on reproduction. Highest reproduction or 'recruitment potential' was associated with mean spring sea-ice conditions and high total annual primary production (Quetin \& Ross 2001), and not heavy winter sea ice as stated in the original hypothesis. The second hypothesis stated that winter-over survival of larvae, and thus recruitment success, would be highest after winters of heavy sea ice (Quetin et al. 1996). 
In this study, we used the size structure of the population of Antarctic krill sampled each January during the first $11 \mathrm{yr}$ of the Palmer LTER to document variability in recruitment success as defined by the strength of the year class 12 mo after spawning. The question was whether there were cycles or trends in recruitment of krill. To date we have documented 2 cycles of recruitment, with 2 sequential strong year classes dominating the population for a 5 to $6 \mathrm{yr}$ period until the next strong year class emerged. Various climate parameters in the Antarctic Peninsula region, including sea ice, have been linked to the El Niño/Southern Oscillation (ENSO) signal (Stammerjohn \& Smith 1996, Yuan \& Martinson 2000, Kwok \& Comiso 2002) through the atmospheric teleconnection (Bjerknes 1969) between the east Pacific region of the Antarctic and the western-central tropical Pacific. The relationship of the episodic recruitment cycle found in the Palmer LTER study region to both the ENSO signal and to seasonal sea-ice parameters derived for the Palmer LTER region is described.

\section{MATERIALS AND METHODS}

Study area, cruise times and stations occupied. The Palmer LTER grid was first established with transect lines spaced $100 \mathrm{~km}$ apart alongshore and stations spaced $20 \mathrm{~km}$ apart from the coast to $200 \mathrm{~km}$ offshore (Waters \& Smith 1992). The first summer (JanuaryFebruary) cruise for the Palmer LTER was in 1993. The mesoscale grid occupied during that cruise has been surveyed each subsequent summer through the summer of 2002, creating a 10-yr time series. The summer study region was between Anvers and Adelaide Islands, and included the 200 to 600 transect lines (Fig. 1). The area surveyed was about $64000 \mathrm{~km}^{2}$ for the summers of 1993 and 1995 to 2002 and $48000 \mathrm{~km}^{2}$ in 1994. The area sampled during November 1991 was considerably smaller, $8000 \mathrm{~km}^{2}$, as ice and time prevented sampling on the inner shelf and to the south of the 500 transect line. Sampling was conducted from the MV 'Polar Duke' from 1991 through 1997 and with the ARSV 'Laurence M. Gould' from 1998 through 2002. Cruises are identified with year and month of start, e.g. '93Jan'. Not all 'standard' 46 stations were sampled on all cruises, due to weather, ice or scheduling issues (Table 1).

Collection. Antarctic krill were usually collected with a $2 \times 2 \mathrm{~m}$ fixed-frame net ( 700 $\mu \mathrm{m}$ stretch mesh, $500 \mu \mathrm{m}$ mesh cod end) towed obliquely between the surface and $120 \mathrm{~m}$ on January cruises and between the surface and $250 \mathrm{~m}$ during 91Nov. The maximum depth of the tow was recorded with either a benthostime-depth recorder or a pressure sensor on the end of the tow cable. The standard depth of $120 \mathrm{~m}$ was chosen based on evidence that krill were seldom found below $120 \mathrm{~m}$ in the summer (Ross et al. 1996). The volume of water filtered was measured with a General Oceanics flowmeter in the center of the net frame. A $1 \times 1 \mathrm{~m}$ fixed-frame net (335 $\mu \mathrm{m}$ mesh and cod end) was also towed at each station to a standard depth of $300 \mathrm{~m}$. If

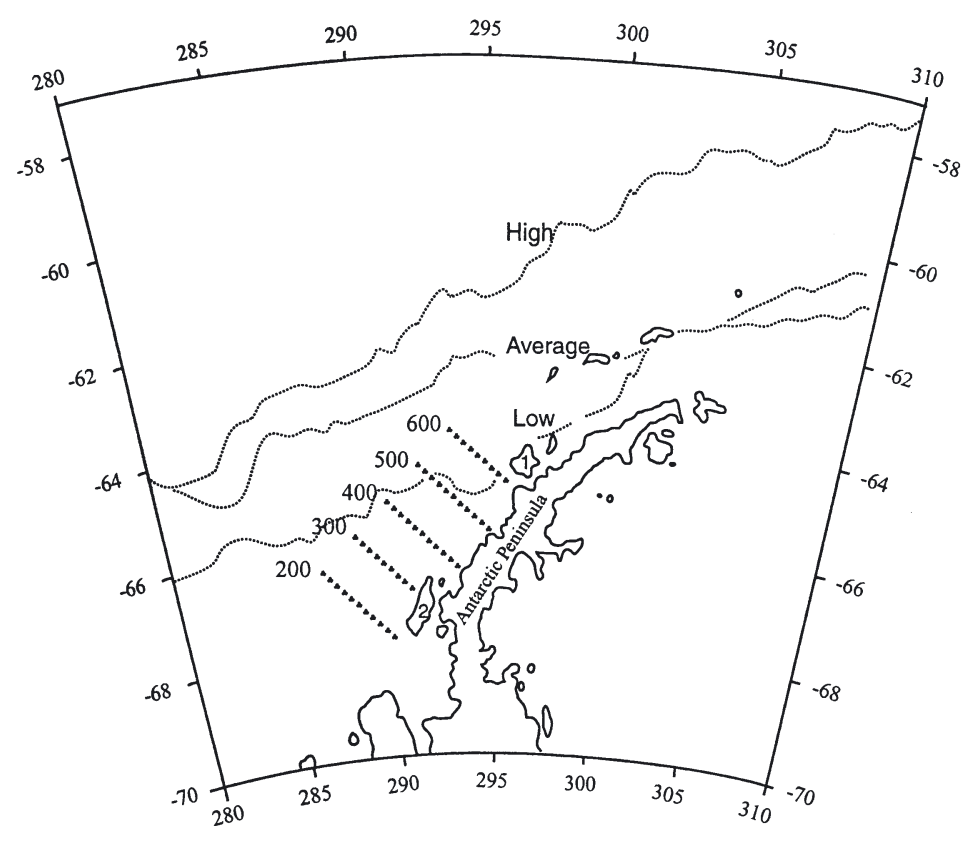

Fig. 1. Palmer LTER grid west of the Antarctic Peninsula, with cardinal lines perpendicular to the coast and numbered at $100 \mathrm{~km}$ intervals from south to north alongshore. Stations along cardinal lines are $20 \mathrm{~km}$ apart and numbered starting from onshore and running offshore. 1: Anvers Island, 2: Adelaide Island. Dotted lines represent winter sea-ice extent in high, average and low years

Table 1. Palmer LTER cruise, sampling dates, transect lines surveyed, and number of the 46 'standard' stations occupied

\begin{tabular}{|lclc|}
\hline Cruise & Sampling dates & Transect lines & No. of stations \\
\hline 91Nov & 12 Nov-19 Nov & 500,600 & 9 \\
93Jan & 8 Jan-6 Feb & 200,300,400,500,600 & 37 \\
94Jan & 11 Jan-6 Feb & 300,400,500,600 & 35 \\
95Jan & 7 Jan-6 Feb & 200,300,400,500,600 & 46 \\
96Jan & 8 Jan-9 Feb & 200,300,400,500,600 & 46 \\
97Jan & 12 Jan-12 Feb & 200,300,400,500,600 & 46 \\
98Jan & 29 Jan-13 Feb & 200,300,400,500,600 & 42 \\
99Jan & 9 Jan-11 Feb & 200,300,400,500,600 & 46 \\
00Jan & 9 Jan-24 Jan & 200,300,400,500,600 & 39 \\
01Jan & 10 Jan-24 Jan & 200,300,400,500,600 & 46 \\
02Jan & 8 Jan-26 Jan & 200,300,400,500,600 & 46 \\
\hline
\end{tabular}


krill were not caught in the $2 \mathrm{~m}$ net, krill from the $1 \mathrm{~m}$ net were measured for length-frequency data. For all 11 cruises, the contents of only four $1 \mathrm{~m}$ tows were used to supplement the $2 \mathrm{~m}$ net analysis. Standard tows were centered on Palmer LTER grid locations, and lasted for approximately $30 \mathrm{~min}$ at ship speeds of 2.0 to 2.5 knots ( 3.7 to $4.6 \mathrm{~km} \mathrm{~h}^{-1}$ ).

Length-frequency analysis. Euphausia superba were measured fresh on board except for the austral spring cruise (91Nov), when total length was measured after preservation in $5 \%$ buffered formalin. Standard Length 1 (Mauchline 1980) of either all individuals or a random subsample of about 100 individual krill was measured. A length-frequency distribution (LFD) based on $1 \mathrm{~mm}$ length increments of the raw numbers from each tow was standardized with the proportion of the catch measured and the volume filtered to arrive at the number of krill per $1000 \mathrm{~m}^{3}$ in each length increment, or the length-density distribution. Data from $91 \mathrm{Nov}$ and $1 \mathrm{~m}$ net tows were adjusted for the different maximum tow depth. Data from all standard stations sampled on the 200,300,400,500, and 600 lines were combined for each cruise length-density distribution. Net tows that included zero densities for all length intervals were included in the analysis.

The maximum likelihood fitting procedure of de la Mare (1994), used in the program CMIX, was used to fit a mixture of normal distributions to the lengthdensity distributions derived from net data. Initial inspection of the length-density distributions (Fig. 2) showed a clear distinction between a mode of small krill about 1 yr old, generally less than $30 \mathrm{~mm}$, and a mode of larger krill composed of all older age classes. Age Classes 5 and 6 were grouped as they were difficult to distinguish. In all cases we initially assumed that 5 age classes in varying numbers were present: Age Class 1 (AC1, krill hatched the previous summer), $\mathrm{AC} 2, \mathrm{AC} 3, \mathrm{AC} 4$ and $\mathrm{AC5} / 6$. In some years there appeared to be 2 modes for the AC1s, and we solved the length-density distributions for 6 mixture components. If the addition of 2 modes to the AC1s minimized the difference between the observed and expected total, we accepted 2 modes for the AC1s.

Output of the CMIX program included the total density and mean total length of each mixture component. The proportion of the AC1s of the total observed population was calculated as an index of recruitment success $\left(R_{1}\right)$, as defined by de la Mare (1994). Absolute recruitment success $\left(R I_{1}\right)$ was the density of the $1 \mathrm{yr}$ old krill (Siegel et al. 1998). For years with 2 modes of AC1, both modes were included. Year classes (YC) were identified as the summer of spawning. For the 2 year classes (YC1990 and YC1991) that dominated our catches in the early 1990s, the Palmer LTER did not have a January cruise the summer they were AC1s, i.e.
January 1991 and January 1992 respectively. For these 2 year classes we estimated recruitment success from the proportion of the year class as AC0 (YC1991 in 91Nov), AC2 (YC1991 in 93Jan and YC1990 in 91Nov) and AC3 (YC1990 in 93Jan). The observed densities of that year class were divided by the observed densities of that year class plus all older year classes, i.e. $R_{2}=$ $\mathrm{AC} 2 /(\mathrm{AC} 2+\mathrm{AC} 3+\mathrm{AC} 4+\mathrm{AC} 5 \& 6)$.

Seasonal ENSO indexes were obtained from the World Wide Web page (http://www.cpc.ncep.noaa. gov/products/analysis_monitoring/ensocycle/soi.html) created by the National Centers for Environmental/ Climate Prediction (NCEP) and the United Kingdom Meteorological Office (UKMO). NCEP and UKMO used sea-surface temperature (SST) in the tropical Pacific between $150^{\circ} \mathrm{W}$ and the dateline to categorize each 3 mo season as neutral or as a strong, moderate or weak El Niño or La Niña. The seasons were January-March, April-June, July-September, and October-December. We assigned each category a ranking: 0 for neutral, 1 for weak, 2 for moderate and 3 for strong El Niño (+) or La Niña (-) periods. We summed the signed austral spring-summer-fall-winter rankings to categorize whether a particular year class was spawned and wintered during a strong, moderate or weak ENSO cycle. The maximum possible rank was \pm 12 .

\section{RESULTS}

The length-density distributions were arranged sequentially by year to illustrate the 2 cycles observed in recruitment over the last decade. Each cycle began with 2 sequential strong year classes, and was 5 to $6 \mathrm{yr}$ long. AC1s dominated at the beginning of a cycle, as in 91Nov, 96Jan and 02Jan. For the first cycle, the first of the 2 strong year classes was YC1990, as inferred from estimates of $R_{2}$ and $R_{3}$ (0.95 and 0.99 respectively). High recruitment indices were also found for the subsequent YC1991: 0.936 and 0.931 as AC0s and AC2s. YC1990 and YC1991 were traced in the lengthdensity distributions as increasingly larger krill through the 96Jan cruise, and YC1995 and YC1996 were traced in the length-density distributions as increasingly larger krill through the 01Jan cruise (Fig. 2). Each cycle ended when another dominant mode of AC1s entered after a series of years of moderate or small year classes. YC1992 and YC1998 (see the length-density distributions in 93Jan and 99Jan) were very small, and were classified as failures. In 02Jan the appearance of the strong YC2001 initiated the beginning of the third cycle.

High interannual variability was present in both $R_{1}$ and the density of AC1s or $R I_{1}$ (Fig. 3). Highest recruit- 

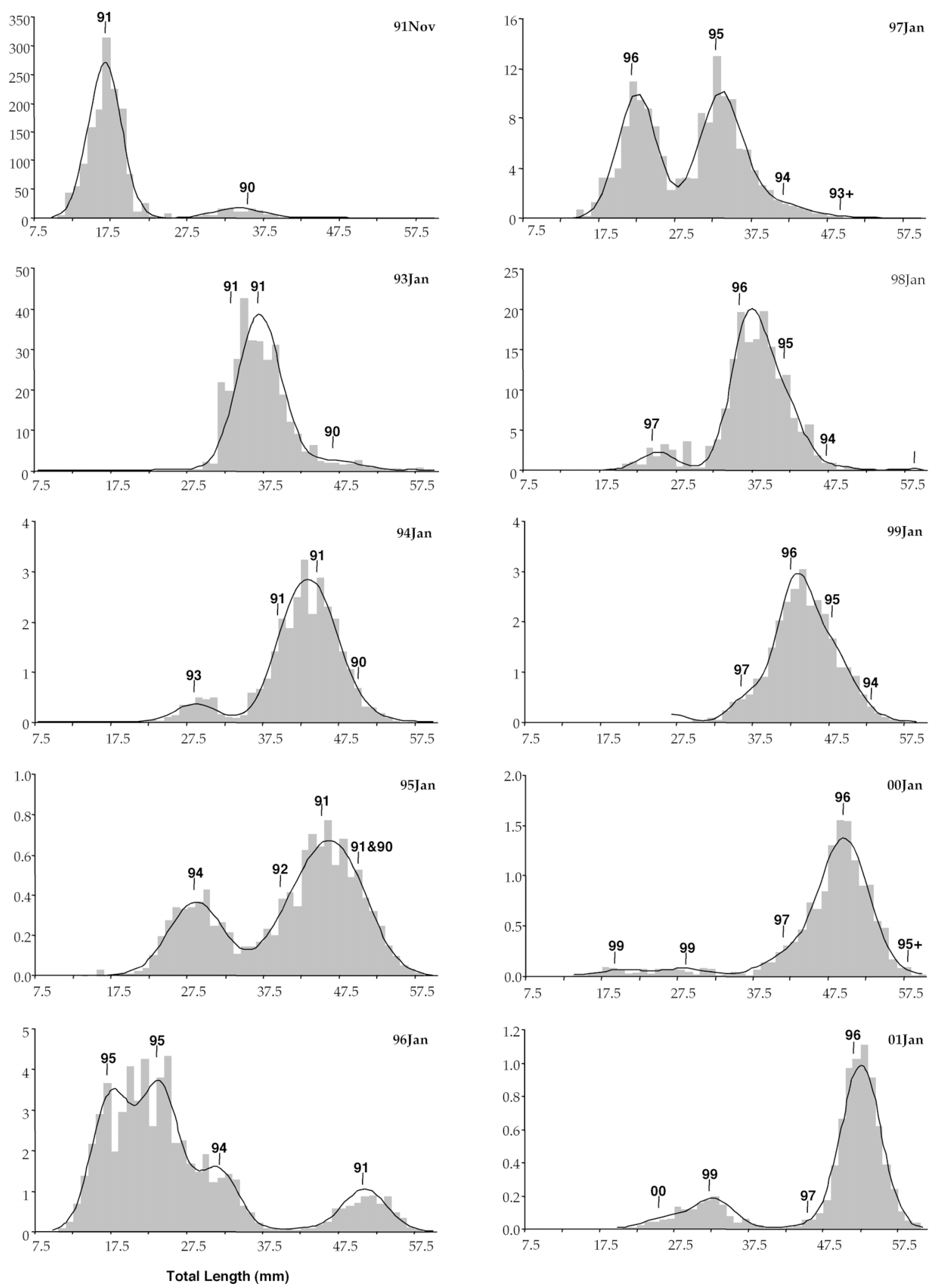

Fig. 2. Euphausia superba. Length-density distributions for the 11 cruises with observed densities in each length bin as solid columns and expected densities from the mixture solution derived with CMIX as the line. The vertical line and number indicate the mean total length of krill in a mode and the year class (YC) of that mode respectively. Two modes are shown for Age Class 1 for YC1995, YC1999 and YC2001

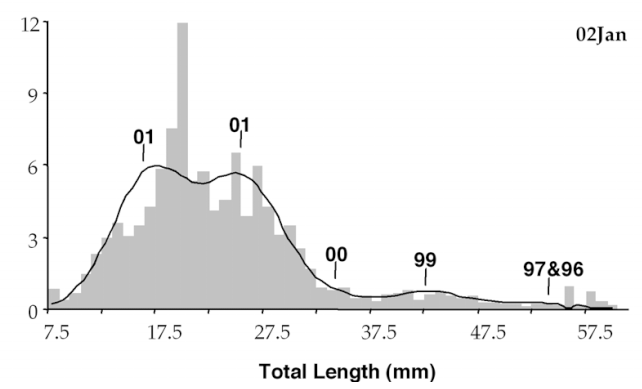




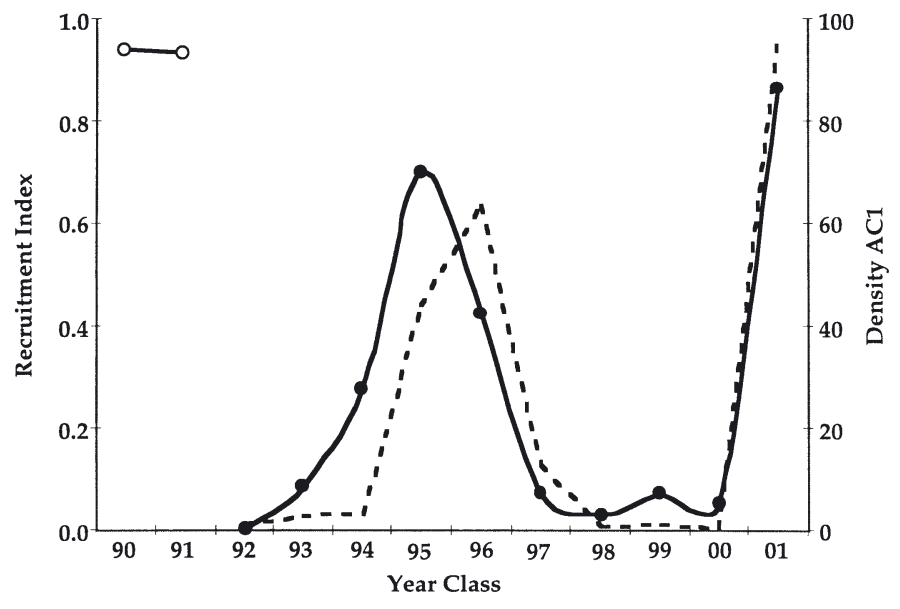

Fig. 3. Euphausia superba. Time-series of recruitment index and density of AC1s in January. The solid line with filled circles is the recruitment index $R_{1}$ calculated from AC1s in January, and with open circles is an estimate of the recruitment index as either $R_{2}$ (YC1990) or from a restricted sampling region (YC1991). The dashed line is the average density (ind. per $1000 \mathrm{~m}$ ) of AC1 in January, for YC1992 through YC2001

ment indexes were found for the year classes of 1990 and 1991, 1995 and 1996, and 2001. Recruitment indexes for YC1990 and YC1991 were plotted with a different symbol because the indexes were not derived from the standard January cruise. Since the area surveyed was significantly smaller than that of the summer cruises, and was biased toward inner shelf stations, the extremely high densities of YC1991 in November (Fig. 2) were also not directly comparable to those from January cruises. Maximum densities of AC1s in January were near 100 individuals per $1000 \mathrm{~m}^{3}$. The pattern of abundance was the same as for $R_{1}$, although the absolute abundance of YC1996 as AC1 was higher than that of YC1995, whereas the reverse was true of $R_{1}$.

Table 2. Euphausia superba. Mean total length (mm) of length mixture distributions as calculated by the methods of de la Mare (1994). - : insufficient numbers to calculate mean total length of that age class. Mean total lengths for $91 \mathrm{Nov}$ were adjusted for shrinkage during preservation $(7.5 \%$, authors' unpubl. data)

\begin{tabular}{|cccccc|}
\hline Cruise & AC1 & AC2 & AC3 & AC4 & AC5+ \\
\hline 91Nov & 16.66 & 35.48 & - & 47.54 & - \\
93Jan & 23.04 & $33.92,36.57$ & 46.29 & - & - \\
94Jan & 28.29 & - & $40.83,44.77$ & 49.62 & - \\
95Jan & 28.20 & - & 40.14 & $44.46,48.51$ & - \\
96Jan & $17.08,23.51$ & 31.17 & 41.65 & - & 50.49 \\
97Jan & 22.12 & 33.18 & 41.21 & 49.03 & - \\
98Jan & 24.77 & 36.68 & 41.38 & 47.86 & 58.99 \\
99Jan & 26.00 & 36.66 & 42.76 & 47.75 & 52.00 \\
00Jan & 19.71 .28 .02 & - & 41.40 & 49.21 & 58.99 \\
01Jan & 25.92 & 32.44 & - & 44.52 & 52.15 \\
02Jan & $16.75,25.35$ & 33.18 & 42.50 & - & 52.50 \\
\hline
\end{tabular}

Thus the relative strengths of these 2 year classes depended on whether the parameter of interest was the recruitment index $\left(R_{1}\right.$, relative to the entire population) or $R I_{1}$, the absolute number of new recruits.

For 3 of the years, including 2 modes in the AC1 mixture improved the fit (Fig. 2, Table 2). In these years young krill $<18 \mathrm{~mm}$ were a high percentage of AC1s. The krill in the small mode had a mean total length between 16.7 and $19.7 \mathrm{~mm}$, and krill in the larger of the 2 modes had a mean total length between 23.5 and $28.0 \mathrm{~mm}$ (Table 2 ). When there was only 1 mode in the AC1 mixture component, the mean total length of AC1s ranged between 22 and $28 \mathrm{~mm}$ (Table 2). In 2 of the years with double modes (1996 and 2002), AC1s were a large proportion of the population, indicating a strong year class hatched from the previous summer's spawning. The length-density distribution from 97Jan also appeared to have an abundant smaller mode around $22 \mathrm{~mm}$, and a less abundant larger mode around $28 \mathrm{~mm}$, but these 2 possible modes could not be resolved. The third year with a double mode (00Jan) of AC1s was a weak year class with a wide size range in AC1s.

The mean total length of the other mixture components also varied but only the year class of 1991 showed 2 distinct modes in older age classes. The total length of the AC2s in January was usually 31 to $33 \mathrm{~mm}$, although 3 of the year classes had an average total length of about $36.5 \mathrm{~mm}$ as AC2s. The average length of the AC3s showed a somewhat different pattern. For all except YC1990 and YC1991, AC3s were between 40 and $43 \mathrm{~mm}$. AC3s in YC1990 and YC1991 were slightly larger. The range in mean total length for the older age classes was broader, with AC4s ranging from 44.5 to $49.6 \mathrm{~mm}$, and $\mathrm{AC} 5 / 6 \mathrm{~s}$ ranging from 50.5 to $59.0 \mathrm{~mm}$. Although the small numbers of animals in the oldest age class makes the estimates of both total length and density less reliable, the largest krill only appeared in years when strong year classes were AC5s and AC6s.

To illustrate the dominance of the 2 sequential strong year classes in the population, we plotted the percentage of the total population in the 2 pairs of year classes (YC1990 and YC1991, YC1995 and YC1996) in January throughout the time series (Fig. 4). The densities of each year class during sequential January cruises also illustrated the dominance of the pair of strong recruitment years (Table 3). In several cases, the density of a year class in the second year of sampling (as $\mathrm{AC} 2 \mathrm{~s})$ is higher than as AC1s, suggest- 


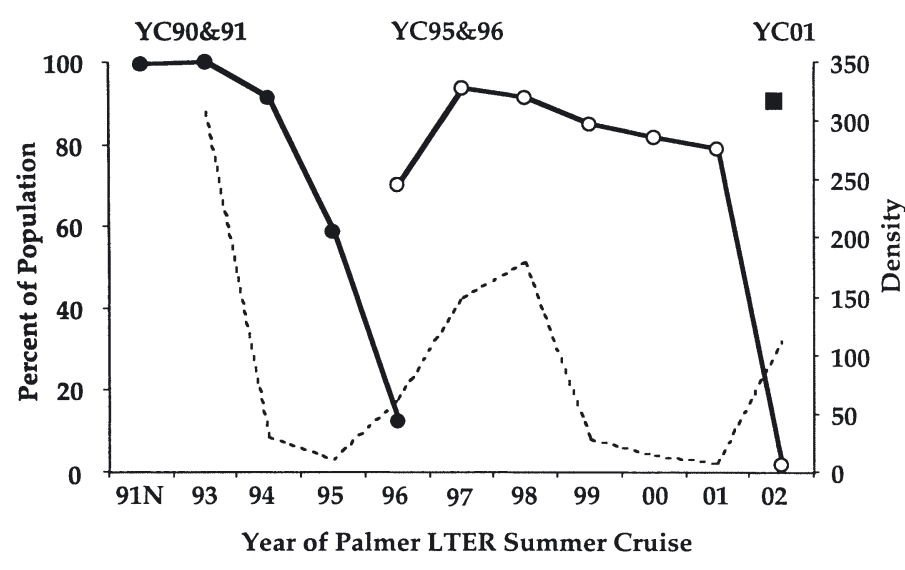

Fig. 4. Euphausia superba. Dominance of population by 2 year classes in cycle. The proportion of the 2 year classes of the total population: YC1990 and YC1991 (•); YC1995 and YC1996 (O); YC2001 (घ). The observed density of the total population in January is the dashed line. $91 \mathrm{~N}$ on $\mathrm{X}$-axis means data from the November 1991 cruise

ing that regions inhabited predominately by AC1s may be under-sampled in our LTER grid or that the LTER region receives immigrants from the south. In Year 4 of the cycle, the pair of year classes still represented 85 to $90 \%$ of the total. The density of the total population in summer showed the impact of this episodic recruitment, varying by a factor of $>35$ during a 5 to 6 yr time period. The highest average density in January (Fig. 4) occurred in the initial $2 \mathrm{yr}$ of the cycle. Although we have no comparable estimates for population densities in 91Jan or 92Jan for the first cycle, the highest density would be predicted in Year 2 of the cycle, as shown by the YC1995-YC1996 pair.

The length of the emerging krill recruitment cycle (5 to 6 yr) was slightly longer than that of the ENSO cycle (3 to $5 \mathrm{yr}$ in recent decades), but less than the time taken for the Antarctic Circumpolar Wave to circle the Southern Ocean, 8 to 10 yr (White \& Peterson 1996). This eastward propagation around Antarctica of interannual anomalies in the ice fields was first documented by Murphy et al. (1995). White \& Peterson (1996) showed that sea ice was at a maximum in a particular region every $4 \mathrm{yr}$ as a result of this phenomenon, which they termed the Antarctic Circumpolar Wave $(\mathrm{ACW})$. The ACW has been linked to the ENSO cycle (White \& Peterson 1996, Yuan et al. 1996), and its major source identified as the western subtropical South Pacific Ocean (Peterson \& White 1998).

The hypothesized mechanisms underlying variations in Antarctic krill recruitment involve the effects of sea ice on reproductive output and on larval survival in the winter. The well-established link between sea-ice dynamics, the ACW and ENSO suggested that we examine the relationship between krill recruitment in the LTER region and the ENSO cycle as an initial approach to understanding episodic recruitment in Antarctic krill. This possible link to ENSO was also supported by the fact that YC failures coincided with the prolonged El Niño of 1991/1993 (YC1992) and the strong El Niño of 1997/1998 (YC1998). The rationale was that a seasonal index of ENSO would summarize the atmospheric teleconnections between the tropical Pacific and the sea ice west of the Antarctic Peninsula during all times relevant to the life cycle of krill, i.e. spring through winter.

The correlation between the absolute value of the summed spring through winter ENSO rankings and the recruitment index was significant, with an $\mathrm{r}^{2}$ of 0.77 for YC1992 through YC2001 (Fig. 5). We did not include YC1991 because the $R_{1}$ was not directly comparable to those calculated from January data. This correlation suggested that recruitment success was higher during periods of neutral or weak El Niño/La

Table 3. Euphausia superba. Densities (ind. per $1000 \mathrm{~m}^{3}$ ) for year classes (YC) from 1990 through 2001 for 5 age classes found annually during January from 1993 through 2002. Strong year classes are given in bold type

\begin{tabular}{|c|c|c|c|c|c|c|c|c|c|c|}
\hline $\mathrm{YC}$ & 93Jan & 94Jan & 95Jan & 96Jan & 97Jan & 98Jan & 99Jan & 00Jan & 01Jan & 02Jan \\
\hline 1990 & 20.73 & 1.34 & 3.24 & & & & & & & \\
\hline 1991 & 274.66 & 24.59 & 3.39 & 7.77 & & & & & & \\
\hline 1992 & 1.05 & - & 1.44 & - & - & & & & & \\
\hline 1993 & & 2.45 & - & 0.45 & 0.87 & 0.95 & & & & \\
\hline 1994 & & & 3.25 & 10.39 & 8.74 & 2.43 & 0.92 & & & \\
\hline 1995 & & & & 44.09 & 73.04 & 47.56 & 7.69 & 0.10 & & \\
\hline 1996 & & & & & 63.32 & 111.93 & 16.63 & 11.13 & 6.59 & \\
\hline 1997 & & & & & & 12.73 & 3.08 & 1.51 & 0.10 & 2.04 \\
\hline 1998 & & & & & & & 0.81 & - & - & - \\
\hline 1999 & & & & & & & & 1.02 & 1.19 & 6.86 \\
\hline 2000 & & & & & & & & & 0.47 & - \\
\hline 2001 & & & & & & & & & & 101.3 \\
\hline
\end{tabular}




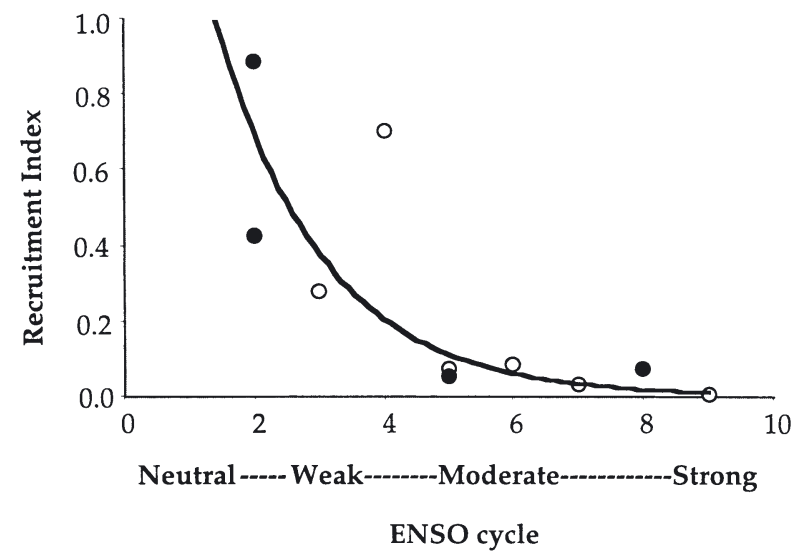

Fig. 5. Euphausia superba. Relationship between the recruitment index $\left(R_{1}\right)$ and the absolute value of a seasonal index of the ENSO cycle. Open circles are dominated by El Niño, closed circles by La Niña. Sea-surface temperatures (SST) in the tropical Pacific between $150^{\circ} \mathrm{W}$ were used to categorize 3 mo periods as neutral or as a strong, moderate or weak (see http://www.cpc.ncep.noaa.gov/products/analysis_ monitoring/ensocycle/soi.html)

Niña, and that the extremes of the ENSO cycle, whether cold or warm, were not associated with high recruitment success.

\section{DISCUSSION}

\section{Gyre-enclosed population or transport}

An inherent assumption in this study is that the recruitment pattern documented represents the response of a 'population' of Antarctic krill to environmental variability in the mesoscale region. Thus, not only immigration and emigration of the adult population, but also advective losses and gains to the population were minimal. The spatial scale of the Palmer LTER grid was in part based on our understanding of oceanic circulation in the region and of the spatial scales involved in the life cycle and population dynamics of Antarctic krill. At the inception of the Palmer LTER, the preponderance of the evidence suggested that there were 1 or 2 gyres within this region (Stein 1988, Stein \& Heywood 1994, Hofmann et al. 1996), which would tend to retain the population in the study region and minimize advective emigration and immigration. More recent research has confirmed that the large-scale circulation consists of a clockwise gyre overlying the shelf south of Anvers Island (Smith et al. 1999). The seaward edge of the gyre is attached to the southern boundary of the Antarctic Circumpolar Current (ACC Boundary), which flows to the northeast inshore of the $2000 \mathrm{~m}$ isobath on the outer edge of the continental shelf. Shoreward, flow is to the south along the inner shelf. The shelf gyre encloses 2 intense smallscale sub-gyres separated at depths greater than $300 \mathrm{~m}$ by bottom topography, with exchanges possible in the upper 200 m, where krill live (Smith et al. 1999).

Some investigators have suggested that Antarctic krill from west of the Antarctic Peninsula, the Scotia Sea and the Weddell Sea form a single population (Miller \& Hampton 1989). Either the Antarctic Peninsula or both the Antarctic Peninsula and northern Weddell Sea regions act as a source for the areas north and east (Murphy et al. 1998, Murphy \& Reid 2001). In a modeling study utilizing historical data, Hofmann et al. (1998) demonstrated that krill would be transported from west of the Antarctic Peninsula to South Georgia on the correct timescales if they enter the rapid flows associated with frontal regions. Will this transport affect the area sampled? In the Palmer LTER region, most of the biomass and almost all AC1 krill occur on the middle and inner shelf (Lascara et al. 1999), and they are not subject to the rapid flows in the frontal systems offshore. In the Palmer LTER study region, spawning female krill occur on the outer shelf and slope (Quetin \& Ross 2001). Thus a portion of the reproductive output may be transported to the northeast when the ACC Boundary intersects their distribution, and serve as a source of young krill at South Georgia 6 mo later. Several pieces of evidence suggest that this 'loss' is either highly variable or a small proportion of the total. First, in August and September 1993, larval krill distribution between Anvers and Adelaide Islands showed neither a latitudinal nor an on/offshore gradient (Frazer et al. 1997), suggesting transport of embryos and larvae within the gyre system from the outer shelf and slope throughout the entire region. Second, the modes of each year class, generally decreasing in numbers as the krill get older, can be followed in Antarctic krill sampled in the Palmer LTER region, which supports the concept of a semi-enclosed population. Third, if the Antarctic Peninsula region was the source of krill around South Georgia, the trends in recruitment should be seen over much larger scales. However, Murphy et al. (1998) show that the recruitment patterns for the northern tip of the Antarctic Peninsula and South Georgia follow the same pattern in only 2 of the 7 years where data exist for both regions. Thus, the preponderance of the evidence suggests that in sampling the Palmer LTER grid we have captured the population dynamics signal of a selfsustaining population of Antarctic krill retained in a gyre system in the region between Anvers and Adelaide Islands (eastern Bellingshausen Sea). This conclusion does not preclude the possibility of a periodic large loss of embryos and larvae to the frontal system of the ACC Boundary and a degree of coherence 
between recruitment and biomass patterns between the Palmer LTER region and areas to the northeast. But it does suggest that subadults found in January are from spawning females in the Palmer LTER area the previous summer, and thus the patterns observed will be a function of the regional environment.

The standardized sampling program (same stations, same time of year) was critical to avoid variability in population parameters due to geographical location or changes in proportions of habitat occupied by different sizes of krill (Bromley 1989, Siegel 2000b, Siegel et al. 2002). Both proportional and absolute recruitment indices will be affected by any bias in the sampling program. The potential biases arise if the known distribution patterns of Antarctic krill are not incorporated into the sampling scheme. In summer the distribution of size groups of krill is not homogeneous, either in the Palmer LTER region (Lascara et al. 1999) or elsewhere in the Southern Ocean (Siegel 2000b). West of the Antarctic Peninsula, juveniles and subadults are generally on the inner shelf, and reproducing adults are on the outer shelf and slope (Siegel 1988, 2000b, Lascara et al. 1999), with abundance increasing from early spring to late summer (Siegel 1988). By fall and winter, krill from the outer shelf have migrated inshore, and the population is concentrated inshore. Thus both time of sampling and the area sampled will impact recruitment indices. Siegel et al. (2002) show clearly that a larger versus a smaller survey area significantly impacts estimates of $R_{1}$, and they suggested that krill recruitment in the Elephant Island region may have been underestimated throughout the 1990s. In this study, except in 1991, we minimized sampling bias by sampling at the same time of year and in an area inclusive of the inner shelf moving offshore to the slope, where few if any krill were found (Palmer LTER unpubl. data). As described below, we viewed the estimates from 91Nov with caution as the cruise was in spring, and annual sea ice restricted sampling to a limited study area. Thus we have tracked those year classes in other samples to verify the results. Also we have not included in this study length-frequency distributions of krill collected at stations from the Grandidier Channel and behind the Biscoe Islands, because those stations were not consistently occupied. Antarctic krill from those stations are generally $\mathrm{AC} 1 \mathrm{~s}$ and $\mathrm{AC} 2 \mathrm{~s}$, and thus without those stations, $R_{1}$ and $R I_{1}$ may underestimate the strength of early year classes.

The data suggested that some immigration/emigration or incomplete sampling of the smallest krill occurred, and that $R_{1}$ was underestimated in some years. First, YC1992 was virtually absent except as AC3s, when they appeared in low numbers. More importantly, for both YC1995 and YC1996 AC2s were more dense than AC1s (Table 3). Either we initially under- sampled the AC1s or significant immigration of individuals belonging to those year classes occurred between their second and third summers. Immigration could come from either the south or the under-sampled region close to the continent. Any $\mathrm{AC} 1 \mathrm{~s}$ behind the Biscoe Islands and in the Grandidier Channel are predicted to move seaward into the sampling area in their third summer as a normal shift in distribution with maturation. If these krill represent a significant proportion of the population in the region, this ontogenetic shift may lead to an increase in the numbers of a year class found seaward of the islands.

\section{Population cycles}

The episodic recruitment documented for Antarctic krill in the Palmer LTER study region consisted of 2 strong year classes followed by 3 to 4 weak year classes (or failures) in each 5 to 6 yr period. The pattern for the time series for Antarctic krill at the tip of the Peninsula in the 1990s differs, however, with a high $R_{1}$ followed by 3 to 4 weak year classes (or failures) (Siegel et al. 2002). The absolute recruitment index $\left(R I_{1}\right)$ for the strong year classes in the 1990s was similar in the 2 regions, with a high $R I_{1}$ for both YC 1995 and YC1996. $R I_{1}$ ranged from 44 to 101 ind. per $1000 \mathrm{~m}^{3}$ in the Palmer LTER region, and 60 to 131 ind. per $1000 \mathrm{~m}^{3}$ in the Elephant Island area (Siegel et al. 2002).

Around South Georgia, diet analyses of predators have been used to suggest patterns in recruitment, as shown by variability in the size of krill consumed (Reid \& Arnould 1996, Reid et al. 1999). In a 7 yr study Reid et al. (1999) documented increasing size in Antarctic krill in the diet of Antarctic fur seals over a 3 to $4 \mathrm{yr}$ period, from a minimum mean of $\sim 39 \mathrm{~mm}$ to a maximum of $\sim 48 \mathrm{~mm}$, and then a repeat of the cycle. The change in size was attributed to changes in the krill population structure, i.e. the average total length of the prey available. We would expect to see such changes in the average length of prey taken in the Palmer LTER area, given the progression of 2 dominant year classes through the population, which results in an increasing mean size until the initiation of the next cycle. Reid et al. (1999) suggested the dominance (or lack) of Class 3 krill was the cause of this cycle in Antarctic fur seal diets at South Georgia and that the decrease in size resulted from a year-class failure, leading to a lack of Class 3 krill a year later. However, care should be taken in assuming that the 3 size classes represent age classes as the size range should include 5 or 6 age classes. In fact, Watkins (1999) analyzed krill from net tows in the same region and showed that the mean total lengths of age classes of Antarctic krill were similar to those in this study and at the tip of the Peninsula. 
Thus Class 3 krill from Reid et al. (1999) will usually include at least 2 age classes, as does the dominant mode in biomass in the Palmer LTER region. However, the pattern does suggest that large shifts in krill population structure will be reflected in predator diets.

A life-history pattern of 3 to 4 weak year classes in a 5 to 6 yr cycle would not be successful in a short-lived crustacean. Antarctic krill may reproduce in their third summer (Cuzin-Roudy 1987b, Siegel \& Loeb 1994), but in this region they usually first reproduce in their fourth summer (Ross \& Quetin 2000), which would make population recovery from a failure difficult if the cycle had only 1 strong year class. Assuming an instantaneous mortality rate of $M=1.0$, Priddle et al. (1988) modeled the effect of a single year of recruitment failure on the population density and found that the population would be reduced to $36.6 \%$ of the stable level. Recovery would take 3 successive years to reach $96 \%$ of the normal level. In this study, both the recovery and decline responses are on shorter timescales than predicted by Priddle et al. (1988). We documented a steep increase in population density after the first strong year class and a steep decrease in population density after the first failure or weak year class (Fig. 4). The steep recovery may be partly due to the more than 10 -fold variability in the reproductive output of Antarctic krill (Quetin \& Ross 2001), which was not known at the time of Priddle et al.'s (1988) model. Thus a strong reproductive year coupled with high survival could lead to the large increases in population density seen over a single year. The steep decline indicates that the assumption of an invariant instantaneous mortality rate might be incorrect, with mortality higher in AC2s and AC3s than in older year classes.

Scattered references to the presence of bimodal LFDs in young-of-the-year or of the presence of smaller than expected $\mathrm{AC} 1 \mathrm{~s}$ in summer exist. In several instances, the small AC1s in summer were found in association with perennial summer ice (Nast 1982, Melnikov \& Spiridonov 1996), and their presence was linked to reproduction under the ice. In another instance, Siegel et al. (1990) suggested that the presence of 2 modes in the NW Weddell Sea was a result of the influx of 1 group from elsewhere. In this study, however, none of the stations were in areas of perennial ice, and immigration and emigration were thought to be minimal.

In the Palmer LTER region, evidence for 2 modes of AC1, the second one with a smaller mean total length than the more common single mode, was found in $3 \mathrm{yr}$. In all cases, 2 modes were resolved when a high proportion of $\mathrm{AC} 1 \mathrm{~s}$ was smaller than $18 \mathrm{~mm}$, whether it was a strong year class or not. We suggest that a high proportion of small AC1s occurred when the reproductive season was prolonged, leading to a wide size range in AC1s. For YC1995, the bimodal year class was associated with a prolonged reproductive season when the oocyte development index was high, there was evidence of recycling in the ovary, and the percentage of post-spawn female krill was low (Table 4). A slight delay in ovarian development during recycling could result in a hiatus between the first and second series of 3 spawning episodes, leading to 2 periods of intense spawning and 2 modes of AC1s. A similar prolonged reproductive season in 2001 is likely the source of the bimodal AC1s for YC2001. The most likely explanation for 2 modes in YC1999 as AC1s lies not in recycling, but in the very low development rate of the ovary (Quetin \& Ross 2001) and the lack of recycling (Table 4). A prolonged spawning season due to slow ovarian development may have led to the large size range of AC1s in 00Jan and thus the 2 modes. Thus a prolonged reproductive season would result from either optimal energy input for the female, with early spawning and recycling, or poor energy input for the female and thus slow and varied ovarian development spread out over a long season. The rapid growth usually seen in the second spring/summer (Ross et al. 2000) will tend to merge the 2 modes, leading to a single mode found as later year classes.

For most long-lived pelagic species for which we have a time series of this length, recruitment has been

Table 4. Euphausia superba. Reproductive characteristics in the Palmer LTER region from 1993 to 1999, as published in Quetin \& Ross (2001). The oocyte development index represents the rate of oocyte development during yolk accumulation. Average percentage from entire sampling area of actively spawning and post-spawning females. Presence of Stage 8 continuing females (i.e. 1 cycle completed, young oocytes ready to repeat cycle) was taken as evidence of recycling. The season can be characterized as delayed (i.e. spawning initiated late in season), nearing completion, or ongoing. The 1999 season appeared to be a season with a mixture, suggesting a prolonged season of low-intensity spawning

\begin{tabular}{|cccccl|}
\hline $\begin{array}{c}\text { Oocyte de- } \\
\text { velopment } \\
\text { index }\end{array}$ & $\begin{array}{c}\text { Actively } \\
\text { spawning } \\
\text { fraction (\%) }\end{array}$ & $\begin{array}{c}\text { Evidence } \\
\text { of } \\
\text { recycling }\end{array}$ & $\begin{array}{c}\text { Post-spawn } \\
\text { fraction } \\
(\%)\end{array}$ & Comment \\
\hline 1993 & 0.31 & 20 & No & 9 & Delayed \\
1994 & 0.71 & 12 & No & 26 & Nearing completion \\
1995 & 0.75 & 12 & Yes & 8 & Ongoing \\
1996 & 0.96 & 60 & Yes & 8 & Ongoing \\
1997 & 0.06 & 3 & No & 6 & Delayed \\
1998 & 0.57 & 10 & No & 40 & Nearing completion \\
1999 & 0.19 & 29 & No & 27 & Mixed \\
\hline
\end{tabular}


shown to be highly variable (Mearns 1979, Morison et al. 1998, Allain et al. 2001, Ottersen \& Stenseth 2001). But rarely is the pattern as strong and repeated as shown for Antarctic krill in the Palmer LTER region. Although observations of cyclic recruitment in invertebrates are not common, Dayton (1989) has shown episodic recruitment in an Antarctic sponge and Drobysheva (1994) (as cited in Siegel 2000b) in an euphausiid in the Barents Sea. Drobysheva (1987, 1994) suggested that an observed 2 to 3 yr cycle in the recruitment of Thysanoëssa inermis, reflected in the euphausiid density, was due to the effects of water temperature on the AC0s. Episodic recruitment in marine fishes is common and often linked to specific oceanic conditions of temperature or visibility (Mearns 1979). Usually the alternation of strong and weak year classes is linked indirectly to meteorological conditions through the effect of wind and temperature on foodweb dynamics and larval survival (Allain et al. 2001, Ottersen \& Stenseth 2001). In one recent study of recruitment in cod in the Barents Sea, the authors examined Barents Sea temperature, the North Atlantic Oscillation and cod recruitment (Ottersen \& Stenseth 2001), and they suggested a mechanism linking largescale atmospheric forcing to cod recruitment through changes in ocean temperature and food availability.

We suggest that an analogous mechanism occurs west of the Antarctic Peninsula, where the ENSO cycle is linked to recruitment in Antarctic krill through seasonal sea-ice dynamics. Antarctic krill have often been described as having many of the characteristics of a small fish, such as anchovy or sardine (Hamner et al. 1983), and their recruitment patterns may be another 'small-fish-like' characteristic. The strong teleconnection between the ENSO cycle in the tropical Pacific and climate in both the Bellingshausen Sea and the region west of the Antarctic Peninsula has been well established (Stammerjohn \& Smith 1997, Kwok \& Comiso 2002). Multiple investigators (Stammerjohn \& Smith 1996, Yuan \& Martinson 2000, Smith \& Stammerjohn 2001, Kwok \& Comiso 2002) have shown that a considerable proportion of the variability in seasonal sea-ice dynamics in that region is linked to tropical climate variability. The effect of sea ice on recruitment in Antarctic krill is mediated through its effect on food availability in austral spring and winter. First, the annual advance and retreat of the pack ice is a major determinant of the spring and summer phytoplankton distribution and productivity (Smith et al. 1996, 1998, 2001). Second, the microbial community living within and on the sea ice in winter and early spring appears to be a critical source of food for larval krill in winter (Quetin et al. 1996).

The index of recruitment success reflects both reproductive output and winter-over larval survival. We have simultaneous measures of recruitment success and reproductive output, one of the major determinants of recruitment success, but not of larval survival. Thus distinguishing the relative importance of these 2 processes on recruitment success is difficult. Reproductive output and winter-over survival of larval krill have been linked to seasonal sea-ice dynamics, both in the Palmer LTER study region (Ross \& Quetin 1991, Quetin et al. 1996, Quetin \& Ross 2001) and in the Antarctic Marine Living Resources (AMLR) study region at the tip of the Antarctic Peninsula (Siegel \& Loeb 1995, Loeb et al. 1997). In a previous paper, we discussed the linkage between sea-ice dynamics and reproductive output in Antarctic krill in the Palmer LTER region. Analysis of multiple aspects of the reproductive cycle in Antarctic krill in a 7 yr time series (1993-1999) suggested that conditions for reproductive output were optimal when both timing of spring retreat and sea-ice extent were close to the long-term mean (climatology) (Quetin \& Ross 2001). Below, we explore possible relationships between $R_{1}$ and sea-ice conditions in the fall, winter and spring following spawning, the time associated with larval survival, to see if particular patterns of sea-ice dynamics fostered high recruitment. Sea-ice data for the Palmer LTER region were derived from multi-frequency passive microwave satellite data supplied by the National Snow and Ice Data Center and analyzed by Stammerjohn et al. (1997) and R. C. Smith \& S. E. Stammerjohn (2001, pers. comm.; for 2000 and early 2001) with the NASA Team algorithm. Sea-ice extent was defined as the area enclosed by the $15 \%$ ice concentration contour, as in previous studies (Zwally et al. 1983).

In contrast to the analysis of Siegel \& Loeb (1995) with data from the tip of the Antarctic Peninsula, in the Palmer LTER region, correlations among the recruitment index and various parameters representing seasonal sea-ice dynamics suggested that extreme conditions were neither necessary nor sufficient for high recruitment success. For example, the $\mathrm{r}^{2}$ of regressions between $R_{1}$ and either maximum extent or maximum area in late winter (September) were $<0.12$. In addition, although timing of maximum area appeared to be an important factor, as recruitment success was only high when the maximum area occurred in August, neither the magnitude of the maximum area nor the timing of retreat were generally critical.

However, specific patterns in the advance and retreat of seasonal sea ice, as shown in Stammerjohn et al. (1997) and Smith \& Stammerjohn (2001), were associated with poor, moderate or high recruitment success. For years in which recruitment success is poor, either there was an early retreat or advance was late with a less than average spring extent. Generally the short period of maximum ice extent in this region 

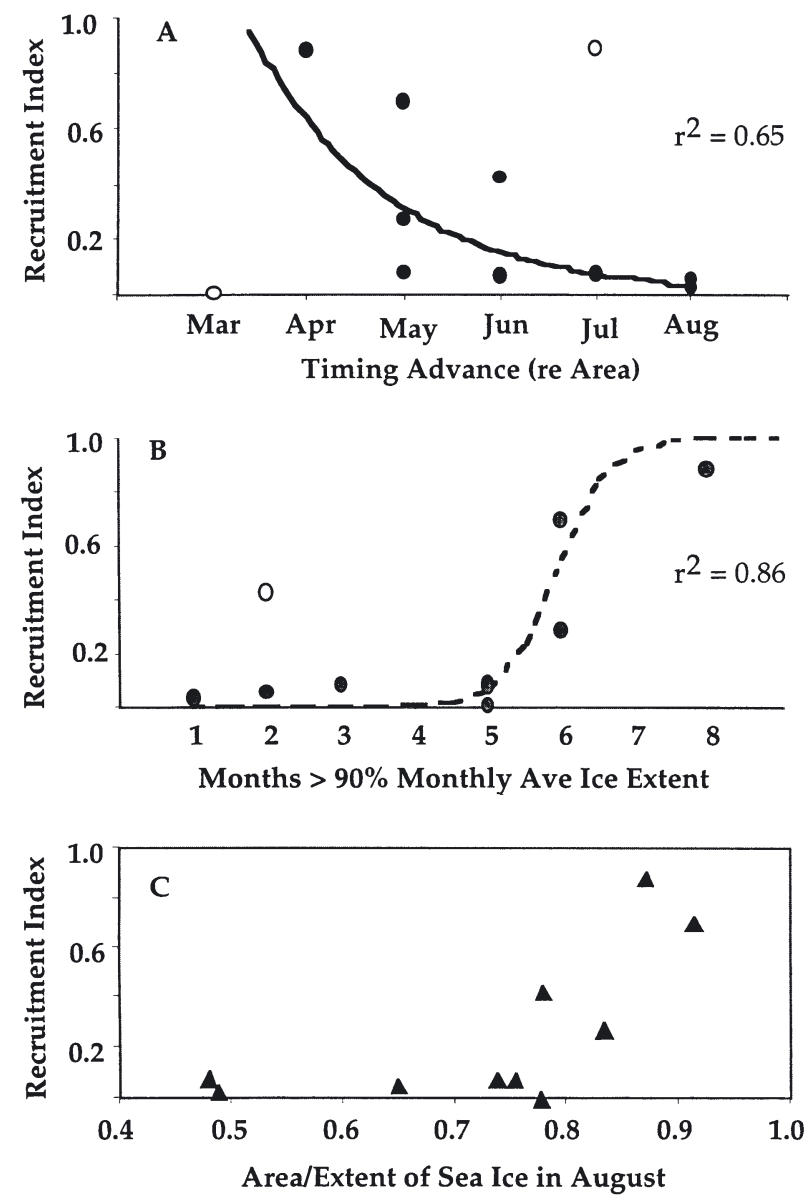

Fig. 6. Euphausia superba. Relationship of the recruitment index $\left(R_{1}\right)$ to seasonal sea-ice parameters. (A) Timing of advance; open circles are not included in the exponential relationship with an $\mathrm{r}^{2}=0.65$. (B) Duration, number of months at greater than $90 \%$ of the 22 yr average of monthly sea-ice extent from April through December; open circle not included in the sigmoidal function with a $\mathrm{r}^{2}=0.86$. (C) Krill habitat as the ratio of sea-ice area to extent in August in the study region

peaks in August or September (Stammerjohn \& Smith 1996). Moderate recruitment was also associated with average timing for advance and slightly-below-average late spring sea ice. Highest recruitment occurred when sea ice advanced by June and was average or close to average through December. Advance by early winter and duration into the spring appeared to be key to recruitment success.

Based on these observations, we plotted $R_{1}$ versus the timing of advance (Fig. 6A), the duration of sea-ice extent (Fig. 6B), and the ratio of area to extent in August (Fig. 6C). Timing of advance was defined as the month prior to sea-ice area extending above the long-term mean or climatology. The definition of duration incorporated the extent to which the pattern of sea-ice coverage of the krill habitat in a particular year conformed to the climatology. Duration was defined as the number of months when sea-ice extent was at least $90 \%$ of the climatology for each month for the entire Palmer LTER region that ranges from Livingston Island to south of Marguerite Bay west of the Antarctic Peninsula. In the Palmer LTER study region, the $90 \%$ of the climatology of sea-ice extent in August, the month of maximum coverage, covers the entire summer sampling region. The underlying concept was that survival of larval krill would be enhanced if the sea-ice microbial community supplied an alternative food source in the winter habitat for a sufficient period. The winter habitat should be the habitat of the population of krill studied, e.g. on the shelf between Anvers and Adelaide Islands, not the larger Palmer LTER area as used in the analysis of Stammerjohn \& Smith (1996). From the patterns of sea-ice advance and retreat, high recruitment success occurred in years when the seaice extent was near average during the entire fall, winter and early spring - all periods of time when food in the water column could be low. The presence of sea ice and its associated food solely in the winter months did not enhance recruitment. The ratio of sea-ice area to sea-ice extent was proposed as a possible index of habitat type. Larval krill are primarily found coupled to the ice in winter, usually with over-rafted and not fast, pancake, or smooth young ice (Quetin et al. 1996, Frazer et al. 1997, 2002). Low area/extent ratios imply low percentage cover, diffuse ice, and/or very young ice (ratios closer to 0.4 ). Higher ratios (0.7 to 1.0) found in winter and early spring are indicative of a high percentage cover and imply that the sea ice is a wellestablished, over-rafted and better krill habitat.

Timing and duration did influence recruitment success, but neither alone explained the variability (Fig. 6). In general an early advance, i.e. May, was necessary for high recruitment, and if the advance was delayed until July or August the year class strength was very low (Fig. 6A). But in 2 years, the YC1992 failure and the YC2001 success, we observed the reverse (open circles in Fig. 6A). Duration accounted for more of the variability (Fig. 6B), with a sigmoidal function (corrected $\mathrm{r}^{2}=0.86$ without YC1996, 0.66 with YC1996) describing the relationship between $R_{1}$ and duration. This appears to be a threshold effect. If sea-ice extent followed the mean (or was more extensive) for at least 6 mo of the fall/winter/spring period the year class was strong. A similar fit of $R_{1}$ and sea-ice area data was not as good. In addition, although a well-developed pack ice environment $(>0.7)$ was present in August in all years when recruitment success was high, there were also years in which the habitat in August was not a sufficient predictor of recruitment success.

Although in general sea ice advance by May and 6 mo of near mean sea ice extent led to recruitment 
success, we also learn about the processes involved in recruitment from the exceptions to this rule. For example, although sea ice advanced very early for YC1992, there was also an early retreat (July). If the microbial community living in the sea ice was the major food source during the late winter and early spring, this early retreat might lead to starvation for the young-ofthe-year and low recruitment success. The timing and duration of spring and summer open-water blooms then become critical. Conversely, the recruitment index for YC1996 was higher than would have been predicted from any of the sea-ice parameters assumed to influence larval survivorship. However, in the summer of 1996, we saw the highest proportion of females reproducing, the largest number of embryos per female, and evidence of recycling or more spawning episodes per female (Quetin \& Ross 2001). All these factors combine to create large numbers of potential recruits, so even if mortality over the winter was high the number of survivors might still be high, as observed. Thus for 1 of the 4 high recruitment years the characteristics of the spawning season appear to be critical for high recruitment. At this juncture, we do not have a long enough simultaneous time series of the multiple factors impacting recruitment success to clearly identify the relative importance of reproductive output and winter-over larval survival in the final strength of the year class. However, the present study is the first step toward understanding the relative importance of the various processes impacting recruitment success.

The differences in the relationships found between $R_{1}$ and reproduction and seasonal sea-ice dynamics between the Palmer LTER region (this study) and the region $450 \mathrm{~km}$ to the north at the tip of the Antarctic Peninsula (Siegel \& Loeb 1995, Siegel et al. 1998, 2002) may help our understanding of how the ecosystem functions. One potential explanation is that a latitudinal gradient exists in the interaction of the life cycle of Antarctic krill with seasonal sea-ice dynamics. We assume that larval survival in winter is enhanced by the presence of sea ice and its associated microbial community. However, conditions leading to larval habitat being covered with sea ice during the time of low food availability in the water column are different depending on location. Unlike at the tip of the Peninsula, in the Palmer LTER region, maximum sea-ice extent does not appear to be necessary for high larval survival. Nearly all (90 to $100 \%$ ) of the region between Anvers and Adelaide Islands is covered for 4 to $6 \mathrm{mo}$ when the sea-ice cycle is close to the $22 \mathrm{yr}$ mean. Extreme sea-ice conditions are not necessary to provide good winter habitat for larval krill. If Antarctic krill at the tip of the Peninsula require maximum extremes in sea-ice conditions for strong year classes, the implication is that they are living near the end of their distributional range for successful reproduction. As a logical consequence, Antarctic krill populations further south would require the minimum extremes for successful reproduction and larval survival. Thus the interaction between the timing and extent of the seasonal sea-ice dynamics, the location of the larval habitat, and the timing of the life cycle of Antarctic krill may lead to different parameters in the seasonal seaice cycle being correlated with high recruitment success. The interactions are complex, and multiple time series from different locations will be necessary to fully understand the mechanisms underlying the link between sea ice and recruitment success.

The original Palmer LTER hypothesis on the linkage between sea-ice dynamics and krill recruitment focused on maximum extent and area (Quetin et al. 1996). This hypothesis is being modified in light of these results and the recent analysis of Quetin \& Ross (2001) on factors influencing reproductive output. In both studies timing and duration of coverage of the habitat appeared to have greater effects than extreme conditions, and average sea-ice dynamics or the climatology were linked to optimal conditions. In addition, looking at a restricted period of time, i.e. winter, was not as illuminating as incorporating conditions in all seasons. Year class strength in Antarctic krill is a function of multiple processes over multiple seasons, and thus it is not surprising to find that climate conditions during the entire time or perhaps the cumulative effects of climate during that time span were significant. The implication of these results is that the krill life cycle in the Palmer LTER region is synchronized with the mean annual cycle of ice dynamics. Deviations from long-term mean conditions in the timing, duration and extent of sea ice will affect krill recruitment success, and depending on the direction of the deviation either reproductive output and/or larval survival will be affected. Given the present warming trend and its effect on sea-ice dynamics west of the Antarctic Peninsula, and the non-linear response of krill recruitment to seasonal sea-ice dynamics, at some point in the future, we would expect the recruitment cycle in the Palmer LTER region to be negatively impacted. We cannot evaluate the ecological impact of variation in the seaice cycle without an understanding of how the timing and magnitude of seasonal sea-ice coverage interfaces with the life cycle of interest.

\footnotetext{
Acknowledgements. We wish to thank the many staff, graduate students, and undergraduate students who contributed to this work. In particular, we would like to acknowledge the efforts of T. Newberger, J. L. Jones, and C. T. Shaw in measuring krill, and J. Schneider in running the CMIX program. We also thank CCAMLR personnel for graciously sending us the CMIX program for LFD analysis. Discussions of seasonal
} 
sea-ice dynamics in the Palmer LTER region with S. Stammerjohn and R. C. Smith were particularly valuable. The comments of A. Atkinson and 2 anonymous reviewers were constructive and enhanced the discussion of the results. This material is based upon work supported by the National Science Foundation, Office of Polar Programs, under Award Nos. OPP-9011927 and OPP-9632763; The Regents of the University of California, the University of California at Santa Barbara (UCSB); and the Marine Science Institute, UCSB. This is Palmer LTER contribution no. 236

\section{LITERATURE CITED}

Allain G, Petitgas P, Lazure P (2001) The influence of mesoscale ocean processes on anchovy (Engraulis encrasicolus) recruitment in the Bay of Biscay estimated with a threedimensional hydrographic model. Fish Oceanogr 10: 151-163

Bjerknes J (1969) Atmospheric teleconnections from the equatorial pacific. Mon Weather Rev 97:163-172

Brinton E, Huntley M, Townsend AW (1986) Larvae of Euphausia superba in the Scotia Sea and Bransfield Strait in March 1984. Development and abundance compared with 1981 larvae. Polar Biol 5:221-234

Brinton E, Loeb V, Macaulay MC, Shulenberger E (1987) Variability of Euphausia superba populations near Elephant Island and the South Shetland Islands: 1981 vs 1984. Polar Biol 7:345-362

Bromley PJ (1989) Evidence for density dependent growth in North Sea gadoids. J Fish Biol Suppl A 35:117-123

Cuzin-Roudy J (1987a) Gonad history of the Antarctic krill Euphausia superba Dana during its breeding season. Polar Biol 7:237-244

Cuzin-Roudy J (1987b) Sexual differentiation in the Antarctic krill Euphausia superba Dana (Crustacea: Euphausiacea). J Crustac Biol 7:518-524

Cuzin-Roudy J (2000) Seasonal reproduction, multiple spawning and fecundity in Northern krill, Meganyctiphanes norvegica, and Antarctic krill, Euphausia superba. Can J Fish Aquat Sci 57:6-15

Cuzin-Roudy J, Labat JP (1992) Early summer distribution of Antarctic krill sexual development in the Scotia-Weddell region: a multivariate approach. Polar Biol 12:65-74

Dayton PK (1989) Interdecadal variation in an Antarctic sponge and its predators from oceanographic climate shifts. Science 245:1484-1486

de la Mare WK (1994) Estimating krill recruitment and its variability. CCAMLR Sci 1:55-69

Drobysheva SS (1987) Populational characteristics of abundant Barents Sea Euphausiacea. ICES CM 1987/L:12

Drobysheva SS (1994) The Barents Sea euphausiids and their role in formation of commercially valuable biological resources. Isledovaniya PINRO. Knipovich Polar Research Institute of Marine Fisheries and Oceanography (PINRO), Murmansk

Everson I (2000) Role of krill in marine food webs: the Southern Ocean. In: Everson I (ed) Krill: biology, ecology and fisheries. Blackwell Science, Oxford, p 194-201

Frazer TK, Quetin LB, Ross RM (1997) Abundance and distribution of larval krill, Euphausia superba, associated with annual sea ice in winter. In: Battaglia B, Valencia J, Walton DWH (eds) Antarctic communities: species, structure and survival. Cambridge University Press, Cambridge, p 107-111

Frazer TK, Quetin LB, Ross RM (2002) Abundance, sizes and developmental stages of larval krill, Euphausia superba, in ice-covered seas west of the Antarctic Peninsula in winter. J Plankton Res 24:1067-1077

Guzman O (1983) Distribution and abundance of Antarctic krill (Euphausia superba) in the Bransfield Strait. In: Schnack SB (ed) On the biology of krill, Euphausia superba. Ber Polarforsch Sonderheft 4:169-190

Hagen W, Van Vleet ES, Kattner G (1996) Seasonal lipid storage as overwintering strategy of Antarctic krill. Mar Ecol Prog Ser 134:85-89

Hamner WM, Hamner PP, Strand SW, Gilmer RW (1983) Behavior of Antarctic krill, Euphausia superba: chemoreception, feeding, schooling, and molting. Science 220: 433-435

Hofmann EE, Klinck JM, Lascara CM, Smith DA (1996) Water mass distribution and circulation west of the Antarctic Peninsula and including Bransfield Strait. In: Ross RM, Hofmann EE, Quetin LB (eds) Foundations for ecological research west of the Antarctic peninsula, Vol 70. American Geophysical Union, Washington, DC, p 61-80

Hofmann EE, Klinck JM, Locarnini RA, Fach B, Murphy E (1998) Krill transport in the Scotia Sea and environs. Antarct Sci 10:406-415

Ichii T, Katayama K, Obitsu N, Ishii H, Naganobu M (1998) Occurrence of Antarctic krill (Euphausia superba) concentrations in the vicinity of the South Shetland Islands: relationship to environmental parameters. Deep-Sea Res 45: 1235-1262

Kottmeier ST, Sullivan CW (1987) Late winter primary production and bacterial production in sea ice and seawater west of the Antarctic peninsula. Mar Ecol Prog Ser 36: $287-298$

Kwok R, Comiso JC (2002) Southern Ocean climate and sea ice anomalies associated with the Southern Oscillation. J Clim 15:487-501

Lascara CM, Hofmann EE, Ross RM, Quetin LB (1999) Seasonal variability in the distribution of Antarctic krill, Euphausia superba, west of the Antarctic Peninsula. Deep-Sea Res I 46:951-984

Laws RM (1985) The ecology of the Southern Ocean. Am Sci 73:26-40

Loeb V, Siegel V, Holm-Hansen O, Hewitt R, Fraser W, Trivelpiece W, Trivelpiece S (1997) Effects of sea-ice extent and krill or salp dominance on the Antarctic food web. Nature 387:897-900

Marschall HP (1988) The overwintering strategy of Antarctic krill under the pack-ice of the Weddell Sea. Polar Biol 9: $245-250$

Mauchline J (1980) Measurement of body length of Euphausia superba Dana. BIOMASS Handbook No. 4 SCAR/ SCOR/IABO/ACMRR

Mearns AJ (1979) Abundance, composition, and recruitment of nearshore fish assemblages in the Southern California mainland shelf. Rep CCOFI 20:111-119

Melnikov AA, Spiridonov VA (1996) Antarctic krill under perennial sea ice in the western Weddell Sea. Antarct Sci 8:323-329

Miller DGM, Hampton I (1989) Biology and ecology of the Antarctic krill (Euphausia superba Dana): a review. Scientific Committee on Antarctic Research and the Scientific Committee on Oceanic Research, Cambridge

Morison AK, Coutin PC, Robertson SG (1998) Age determination of black bream, Acanthopagrus butcheri (Sparidae), from the Grippsland Lakes of south-eastern Australia indicates slow growth and episodic recruitment. Mar Freshw Res 49:491-498

Murphy EJ, Reid K (2001) Modelling Southern Ocean krill population dynamics: biological processes generating 
fluctuations in the South Georgia ecosystem. Mar Ecol Prog Ser 217:175-189

Murphy EJ, Clarke A, Symon C, Priddle J (1995) Temporal variation in Antarctic sea-ice: analysis of a long term fastice record from the South Orkney Islands. Deep-Sea Res I 42:1045-1062

Murphy EJ, Watkins JL, Reid K, Trathan PN and 6 others (1998) Interannual variability of the South Georgia marine ecosystem: biological and physical sources of variation in the abundances of krill. Fish Oceanogr 7:381-390

Nast F (1982) Krill caught during FIBEX 1981. Arch Fisch Wiss 33:61-84

Nicol S (2000) Understanding krill growth and aging: the contribution of experimental studies. Can J Fish Aquat Sci 57:168-177

Nicol S, de la Mare WK, Stolp M (1995) The energetic cost of egg production in Antarctic krill (Euphausia superba Dana). Antarct Sci 7:25-30

O'Brien DP (1987) Direct observations of the behavior of Euphausia superba and Euphausia crystallorophias (Crustacea: Euphausiacea) under pack ice during the Antarctic winter of 1985. J Crustac Biol 7:437-448

Ottersen G, Stenseth NC (2001) Atlantic climate governs oceanographic and ecological variability in the Barents Sea. Limnol Oceanogr 46:1774-1780

Peterson RG, White WB (1998) Slow oceanic teleconnections linking the Antarctic Circumpolar Wave with the tropical El Niño-Southern Oscillation. J Geophys Res 103: 24573-24583

Priddle J, Croxall JP, Everson I, Heywood RB, Murphy EJ, Prince PA, Sear CB (1988) Large-scale fluctuations in distribution and abundance of krill-a discussion of possible causes. In: Sahrhage D (ed) Antarctic Ocean, resources variability. Springer-Verlag, Berlin, p 169-182

Quetin LB, Ross RM (1992) A Long-Term Ecological Research strategy for polar environmental research. Mar Pollut Bull 25:233-238

Quetin LB, Ross RM (2001) Environmental variability and its impact on the reproductive cycle of Antarctic krill. Am Zool 41:74-89

Quetin LB, Ross RM, Frazer TK, Haberman KL (1996) Factors affecting distribution and abundance of zooplankton, with an emphasis on Antarctic krill, Euphausia superba. In: Ross RM, Hofmann EE, Quetin LB (eds) Foundations for ecological research west of the Antarctic peninsula, Vol 70. American Geophysical Union, Washington, DC, p 357-371

Reid K, Arnould JPY (1996) The diet of Antarctic fur seals Arctocephalus gazella during the breeding season at South Georgia. Polar Biol 16:105-114

Reid K, Watkins JL, Croxall JP, Murphy EJ (1999) Krill population dynamics at South Georgia 1991-1997, based on data from predators and nets. Mar Ecol Prog Ser 177: 103-114

Ross RM, Quetin LB (1983) Spawning frequency and fecundity of the Antarctic krill Euphausia superba. Mar Biol 77: 201-205

Ross RM, Quetin LB (1986) How productive are Antarctic krill? BioSci 36:264-269

Ross RM, Quetin LB (1989) Energetic cost to develop to the first feeding stage of Euphausia superba Dana and the effect of delays in food availability. J Exp Mar Biol Ecol 133:103-127

Ross RM, Quetin LB (1991) Ecological physiology of larval euphausiids, Euphausia superba (Euphausiacea). Mem Queens Mus 31:321-333

Ross RM, Quetin LB (2000) Reproduction in Euphausiacea. In:
Everson I (ed) Krill: biology, ecology and fisheries. Blackwell Science, Cambridge, p 150-181

Ross RM, Quetin LB, Lascara CM (1996) Distribution of Antarctic krill and dominant zooplankton west of the Antarctic Peninsula. In: Ross RM, Hofmann EE, Quetin LB (eds) Foundations for ecological research west of the Antarctic peninsula, Vol 70. American Geophysical Union, Washington, DC, p 199-218

Ross RM, Quetin LB, Baker KS, Vernet M, Smith RC (2000) Growth limitation in young Euphausia superba under field conditions. Limnol Oceanogr 45:31-43

Siegel V (1988) A concept of seasonal variation of krill (Euphausia superba) distribution and abundance west of the Antarctic Peninsula. In: Sahrhage D (ed) Antarctic ocean and resources variability. Springer-Verlag, Berlin, p 219-230

Siegel V (2000a) Krill (Euphausiacea) demography and variability in abundance and distribution. Can J Fish Aquat Sci 57:151-167

Siegel V (2000b) Krill (Euphausiacea) life history and aspects of population dynamics. Can J Fish Aquat Sci 57:130-150

Siegel V, Loeb V (1994) Length and age at maturity of Antarctic krill. Antarct Sci 6:479-482

Siegel V, Loeb V (1995) Recruitment of Antarctic krill (Euphausia superba) and possible causes for its variability. Mar Ecol Prog Ser 123:45-56

Siegel V, Bergström B, Strömberg JO, Schalk P (1990) Distribution, size frequencies and maturity stages of krill, Euphausia superba, in relation to sea ice in the northern Weddell Sea. Polar Biol 10:549-557

Siegel V, Loeb V, Gröger J (1998) Krill (Euphausia superba) density, proportional and absolute recruitment and biomass in the Elephant Island region (Antarctic Peninsula) during the period 1977 to 1997. Polar Biol 19:393-398

Siegel V, Bergström B, Mühlenhardt-Siegel U, Thomasson M (2002) Demography of krill in the Elephant Island area during summer 2001 and its significance for stock recruitment. Antarct Sci 14:162-170

Smetacek V, Scharek R, Nothig EM (1990) Seasonal and regional variation in the pelagial and its relationship to the life history cycle of krill. In: Kerry KR, Hempel G (eds) Antarctic ecosystems: ecological change and conservation. Springer-Verlag, Berlin, p 103-114

Smith DA, Hofmann EE, Klinck JM, Lascara CM (1999) Hydrography and circulation of the West Antarctic Peninsula continental shelf. Deep-Sea Res I 46:925-949

Smith RC, Stammerjohn SE (2001) Variations of surface air temperature and sea-ice extent in the western Antarctic Peninsula region. Ann Glaciol 33:493-500

Smith RC, Baker KS, Fraser WR, Hofmann EE and 7 others (1995) The Palmer LTER: a Long-Term Ecological Research program at Palmer Station, Antarctica. Oceanography 8:77-86

Smith RC, Dierssen HM, Vernet M (1996) Phytoplankton biomass and productivity in the Western Antarctic Peninsula region. In: Ross RM, Hofmann EE, Quetin LB (eds) Foundations for ecological research west of the Antarctic peninsula, Vol 70. American Geophysical Union, Washington, DC, p 333-356

Smith RC, Baker KS, Byers ML, Stammerjohn SE (1998) Primary productivity of the Palmer Long Term Ecological Research area and the Southern Ocean. J Mar Syst 17: 245-259

Smith RC, Baker KS, Dierssen HM, Stammerjohn SE, Vernet M (2001) Variability of primary production in an Antarctic marine ecosystem as estimated using a multi-scale sampling strategy. Am Zool 41:40-56 
Spiridonov VA, Gruzov EN, Pushkin AF (1985) Investigations of schools of Antarctic Euphausia superba under the ice. Zool Zh 64:1655-1660

Stammerjohn SE, Smith RC (1996) Spatial and temporal variability of western Antarctic Peninsula sea ice coverage. In: Ross RM, Hofmann EE, Quetin LB (eds) Foundations for ecological research west of the Antarctic peninsula, Vol 70. American Geophysical Union, Washington, DC, p 81-104

Stammerjohn SE, Smith RC (1997) Opposing Southern Ocean climate patterns as revealed by trends in regional sea ice coverage. Clim Change 37:617-639

Stammerjohn SE, Baker KS, Smith RC (1997) Sea ice indexes for Southern Ocean regional marine ecology studies. Scripps Institute of Oceanography, La Jolla, CA

Stein M (1988) Variation of geostrophic circulation off the Antarctic Peninsula and in the Southwest Scotia Sea. In: Sahrhage D (ed) Antarctic Ocean and resources variability. Springer-Verlag, Berlin, p 81-91

Stein M, Heywood RB (1994) Antarctic environment-physi-

Editorial responsibility: Michael Landry (Contributing Editor), Honolulu, Hawaii, USA cal oceanography: the Antarctic Peninsula and Southwest Atlantic region of the Southern Ocean. In: ElSayed SZ (ed) Southern Ocean ecology - the BIOMASS perspective. Cambridge University Press, Cambridge, p 11-24

Waters KJ, Smith RC (1992) Palmer LTER: a sampling grid for the Palmer LTER program. Antarct J US 27:236-239

Watkins J (1999) A composite recruitment index to describe interannual changes in the population structure of Antarctic krill at South Georgia. CCAMLR Sci 6:71-84

White WB, Peterson RG (1996) An Antarctic circumpolar wave in surface pressure, wind, temperature and sea-ice extent. Nature 380:699-702

Yuan X, Martinson DG (2000) Antarctic sea ice extent variability and its global connectivity. J Clim 13:1697-1717

Yuan X, Cane MA, Martinson DG (1996) Cycling around the South Pole. Nature 380:673-674

Zwally HJ, Parkinson CL, Comiso JC (1983) Variability of Antarctic sea ice and changes in carbon dioxide. Science 220:1005-1012

Submitted: August 6, 2002; Accepted: May 8, 2003

Proofs received from author(s): September 3, 2003 